\title{
Removal of High-Concentration Sulfate Ions from the Sodium Alkali FGD Wastewater Using Ettringite Precipitation Method: Factor Assessment, Feasibility, and Prospect
}

\author{
Ping Fang $\mathbb{D}$, Zi-jun Tang, Xiong-bo Chen $\mathbb{D}$, Jian-hang Huang, Zhi-xiong Tang, \\ and Chao-ping Cen $\mathbb{D}$
}

South China Institute of Environmental Sciences, Ministry of Environmental Protection, Guangzhou 510655, China

Correspondence should be addressed to Chao-ping Cen; cenchaoping@scies.org

Received 6 December 2017; Revised 6 April 2018; Accepted 19 April 2018; Published 3 June 2018

Academic Editor: Pedro Avila Pérez

Copyright (c) 2018 Ping Fang et al. This is an open access article distributed under the Creative Commons Attribution License, which permits unrestricted use, distribution, and reproduction in any medium, provided the original work is properly cited.

\begin{abstract}
The feasibility of removal of sulfate ions from the sodium alkali FGD wastewater using the ettringite precipitation method was evaluated. Factors affecting the removal of sulfate ions, such as $\mathrm{NaAlO}_{2}$ dosage, $\mathrm{Ca}(\mathrm{OH})_{2}$ dosage, solution temperature, anions $\left(\mathrm{Cl}^{-}, \mathrm{NO}_{3}{ }^{-}\right.$and $\left.\mathrm{F}^{-}\right)$, and heavy metal ions $\left(\mathrm{Mg}^{2+}\right.$ and $\left.\mathrm{Mn}^{2+}\right)$, were investigated, and the optimal experimental conditions for the removal of sulfate ions were determined. Experimental results indicate that the ettringite precipitation method can effectively remove $\mathrm{SO}_{4}{ }^{2-}$ with removal efficiency of more than $98 \%$. All the investigated factors have influences on the removal of sulfate ions, and among them, the dosage of reagents, solution temperature, and fluoride ions have the strongest influence. In addition, the method can effectively synergistically remove $\mathrm{F}^{-}$and heavy metal ions with removal efficiencies of more than $90 \%$ and $99 \%$, respectively; meanwhile, $\mathrm{Cl}^{-}$and $\mathrm{NO}_{3}{ }^{-}$also can be removed minimally by the method. The result of actual wastewater treatment shows that the method is feasible for treating high-concentration sulfate wastewater. The ettringite precipitation method has the potential to be a commercial application in the future.
\end{abstract}

\section{Introduction}

At present, the wet flue gas desulfurization (WFGD) is the most commonly used technology in the field of industrial flue gas desulfurization in China [1]. For power plant flue gas desulfurization, the main technology used in China is limestone-gypsum wet process. High desulfurization efficiency and gypsum recycling are the main advantages of this technology. However, some disadvantages, such as the complex system, higher investment cost, and requirement for a large area, have limited the application of this technology in the flue gas desulfurization of industrial boilers and furnaces in China. Therefore, the sodium alkali (NaOH) FGD technology with relatively simple process and high $\mathrm{SO}_{2}$ removal efficiency $(>95 \%)$ is widely used in the flue gas desulfurization of industrial boilers and furnaces. However, there are some shortcomings in this technology that need further improvement. One of the major problems is the disposal of complex and sulfate-rich wastewater.
The sulfate $\left(\mathrm{SO}_{4}{ }^{2-}\right)$ concentration in the sodium alkali $(\mathrm{NaOH}) \mathrm{FGD}$ wastewater is generally more than $10,000 \mathrm{mg} / \mathrm{L}$; the maximum can be greater than $20,000 \mathrm{mg} / \mathrm{L}$. In addition, the wastewater also contains a large number of inorganic anions $\left(\mathrm{NO}_{3}{ }^{-}, \mathrm{Cl}^{-}\right.$, and $\left.\mathrm{F}^{-}\right)$and heavy metal ions $\left(\mathrm{Mg}^{2+}\right.$ and $\left.\mathrm{Mn}^{2+}\right)$. Though $\mathrm{SO}_{4}{ }^{2-}$ is a common and nontoxic component of various types of water bodies, high concentrations of $\mathrm{SO}_{4}{ }^{2-}$ in the water can cause a series of serious environmental problems, leading to water mineralization, metal corrosion, pipes and equipment scaling, toxic hydrogen sulfide release, and disruption in the balance of the natural sulfur cycle [2-5]. In addition, high concentrations of $\mathrm{SO}_{4}{ }^{2-}(>600 \mathrm{mg} / \mathrm{L})$ in the water can cause laxative effects in mammals [6]. Hence, to protect the environment, the $\mathrm{SO}_{4}{ }^{2-}$ concentration in the industrial effluents is set ranging from $250 \mathrm{mg} / \mathrm{L}$ to $500 \mathrm{mg} / \mathrm{L}$ in many countries [6]; for example, the sulfate ion concentration limit values in the industrial recycling water and surface water are all set as $250 \mathrm{mg} / \mathrm{L}$ in China. Hence, in order to meet the discharge standard or achieve the recycling of 
desulfurization wastewater, it is necessary to remove the sulfate ion in the sodium alkali FGD wastewater.

Currently, several technologies, such as biological treatment $[7,8]$, membrane filtration [9], adsorption [10], ion exchange $[11,12]$, electrocoagulation [13], crystallization [14, 15], and chemical precipitation [16], have been developed to treat sulfate in water. However, these methods are not very suitable for the treatment of high concentration of $\mathrm{SO}_{4}{ }^{2-}$ wastewater, except the chemical precipitation method. The chemical precipitation method mainly includes lime precipitation [6], barium chloride precipitation $[17,18]$, and ettringite $\left(\mathrm{Ca}_{6} \mathrm{Al}_{2}(\mathrm{OH})_{12}\left(\mathrm{SO}_{4}\right)_{3}\right.$. $\left.26 \mathrm{H}_{2} \mathrm{O}\right)$ precipitation methods [19]. The limestone precipitation method is widely used in the field of water treatment; however, due to the relatively high solubility of gypsum [19], the $\mathrm{SO}_{4}{ }^{2-}$ removal efficiency is low. The barium chloride precipitation method can reach high $\mathrm{SO}_{4}{ }^{2-}$ removal efficiency, but a large number of corrosive chloride ions and toxic barium ions will be introduced into the water; besides, barium chloride is more expensive than lime, so the technology is rarely used in the field of flue gas desulfurization wastewater treatment.

Compared with the above methods, the ettringite precipitation method is considered as an effective method for treating high-concentration sulfate effluents. In this method, lime and aluminum salts are added into the wastewater to react with sulfate to form insoluble ettringite $(\mathrm{pKsp}=111.6)$ [20], and then sulfate is effectively removed. The ettringite precipitation method has become a preferred method due to its high removal efficiency and cost-effectiveness, and many studies have used this method to treat industrial wastewaters, such as aluminum anodizing, textile industries, and mine water [19-21]. However, in existing researches the sulfate concentrations in simulated or actual wastewaters were usually lower; hence, anions and heavy metal ions were not considered in the removal of sulfate; meanwhile, there exists little information on the removal of $\mathrm{SO}_{4}{ }^{2-}$ from the sodium alkali $(\mathrm{NaOH}) \mathrm{FGD}$ wastewater using the method in the literatures.

The aims of this study are to evaluate the feasibility of removal of high-concentration $\mathrm{SO}_{4}{ }^{2-}$ from the sodium alkali FGD wastewater by using the ettringite precipitation method and investigate the influence of different parameters on $\mathrm{SO}_{4}{ }^{2-}$ removal, in particular, anions and heavy metal ions. In addition, the removal of $\mathrm{SO}_{4}{ }^{2-}$ and other ions in actual sodium alkali FGD wastewater by using ettringite precipitation method was also studied. Finally, the optimal experimental conditions for the removal of high-concentration sulfate ions were determined.

\section{Experimental Section}

2.1. Materials. $\mathrm{Na}\left(\mathrm{SO}_{4}\right)_{2}, \mathrm{NaAlO}_{2}, \mathrm{Ca}(\mathrm{OH})_{2}, \mathrm{NaF}, \mathrm{NaCl}$, $\mathrm{KNO}_{3}, \mathrm{NaOH}, \mathrm{MgSO}_{4}, \mathrm{MnSO}_{4}$, and $\mathrm{HNO}_{3}$ were of analytical grade and used directly without purification. $\mathrm{NaAlO}_{2}$ and $\mathrm{Ca}$ $(\mathrm{OH})_{2}$ were used as aluminum and calcium sources in this study. All reagents were purchased from Guangzhou Chemical Reagent Factory. The sulfate-rich simulated wastewater used in this study was prepared by dissolving $\mathrm{Na}_{2} \mathrm{SO}_{4}$ in deionized water to get initial $\mathrm{SO}_{4}{ }^{2-}$ concentration of $10,000 \mathrm{mg} / \mathrm{L}$. The initial $\mathrm{pH}$ of the solution was adjusted using $\mathrm{HNO}_{3}(1.0 \mathrm{~mol} / \mathrm{L})$ and $\mathrm{NaOH}(1.0 \mathrm{~mol} / \mathrm{L})$.
TABle 1: Results of anions removal.

\begin{tabular}{lccccc}
\hline & $\mathrm{SO}_{4}{ }^{2-}$ & $\mathrm{Cl}^{-}$ & $\mathrm{F}^{-}$ & $\mathrm{NO}_{3}{ }^{-}$ & $\mathrm{pH}$ \\
\hline Actual wastewater, mg/L & $15,274.8$ & 205.56 & 101.43 & 58.30 & 7.8 \\
$\begin{array}{l}\text { Purified wastewater, mg/L } \\
\text { Average removal }\end{array}$ & 172.61 & 199.71 & 7.95 & 54.94 & 13.1 \\
efficiency, \% & 98.87 & 2.85 & 92.16 & 5.76 & - \\
\hline
\end{tabular}

TABLE 2: Results of heavy metal ions removal.

\begin{tabular}{lcccccc}
\hline & $\mathrm{Cr}^{2+}$ & $\mathrm{Mg}^{2+}$ & $\mathrm{Mn}^{2+}$ & $\mathrm{Ni}^{2+}$ & $\mathrm{Pb}^{2+}$ & $\mathrm{Zn}^{2+}$ \\
\hline $\begin{array}{l}\text { Actual wastewater, } \\
\mathrm{mg} / \mathrm{L}\end{array}$ & 3.55 & 15.48 & 22.76 & 5.53 & 5.15 & 5.29 \\
$\begin{array}{l}\text { Purified wastewater, } \\
\text { mg/L }\end{array}$ & - & 0.0102 & 0.0019 & - & - & - \\
$\begin{array}{l}\text { Average removal } \\
\text { efficiency, \% }\end{array}$ & 100 & 99.93 & 99.99 & 100 & 100 & 100 \\
\hline
\end{tabular}

The actual sodium alkali $(\mathrm{NaOH})$ FGD wastewater was obtained from a ceramic production enterprise located in Guang Dong Province, China. The composition of the ions in the wastewater was analyzed and the results are shown in Tables 1 and 2 (in Section 3.8).

2.2. Analytical Methods. The concentrations of $\mathrm{SO}_{4}{ }^{2-}, \mathrm{NO}_{3}{ }^{-}$, $\mathrm{F}^{-}$, and $\mathrm{Cl}^{-}$in the solution were analyzed with an ion chromatography system (Metrohm 883, Switzerland). The concentrations of heavy metal ions, such as $\mathrm{Mg}^{2+}$ and $\mathrm{Mn}^{2+}$, were measured using an inductively coupled plasma emission spectrometer (ICP-AES 710, Agilent Technologies). An MP511 pH detector (Shanghai Precision Instruments Co., Ltd.) was used to determine the $\mathrm{pH}$ of the solution.

2.3. Removal of Sulfate Ions. Experiments were performed on a six league electric blender (ZR4-6, China). The experimental steps of the ettringite precipitation method are as follows: (1) $1 \mathrm{~L}$ of solution sample was taken in a glass reactor, and a certain amount of $\mathrm{Ca}(\mathrm{OH})_{2}$ and $\mathrm{NaAlO}_{2}$ was added to the solution. (2) Then, the sample was stirred at a certain speed for a certain time. (3) Finally, the sample was taken and filtered under vacuum using a $0.45 \mu \mathrm{m}$ microporous membrane filter. The filtrates were analyzed for $\mathrm{SO}_{4}{ }^{2-}$ and other ions, and finally, the $\mathrm{SO}_{4}{ }^{2-}$ and other ions removal efficiencies were calculated by (1). According to the above steps, batch experiments effecting different experimental conditions on $\mathrm{SO}_{4}{ }^{2-}$ removal were implemented, including $\mathrm{Ca}(\mathrm{OH})_{2}$ dosage (the molar ratios of $\mathrm{Ca}(\mathrm{OH})_{2}$ to $\mathrm{SO}_{4}{ }^{2-}$ of $1 \sim 6: 1$ ), $\mathrm{NaAlO}_{2}$ dosage (the molar ratios of $\mathrm{NaAlO}_{2}$ to $\mathrm{SO}_{4}{ }^{2-}$ of $\left.0.7 \sim 3: 1\right)$, solution initial $\mathrm{pH}(3.0 \sim 11.0)$, solution temperature $\left(25 \sim 80^{\circ} \mathrm{C}\right)$, reaction time $(15 \sim 120 \mathrm{~min})$, stirring speed $(100 \sim 500 \mathrm{r} / \mathrm{min})$, and the concentrations of $\mathrm{Cl}^{-}$ (500 4000 mg/L), $\mathrm{NO}_{3}{ }^{-}(100 \sim 2000 \mathrm{mg} / \mathrm{L}), \mathrm{F}^{-}(200 \sim 1000 \mathrm{mg} / \mathrm{L})$, $\mathrm{Mg}^{2+}(50 \sim 1000 \mathrm{mg} / \mathrm{L})$, and $\mathrm{Mn}^{2+}(50 \sim 1000 \mathrm{mg} / \mathrm{L})$ :

$$
\eta=\frac{C_{0}-C_{t}}{C_{0}} \times 100 \%,
$$

where $\eta$ is the $\mathrm{SO}_{4}{ }^{2-}$ or other ions removal efficiency and $C_{0}$ and $C_{t}$ are the initial and final $\mathrm{SO}_{4}{ }^{2-}$ or other ions concentrations of solutions $(\mathrm{mg} / \mathrm{L})$, respectively. 


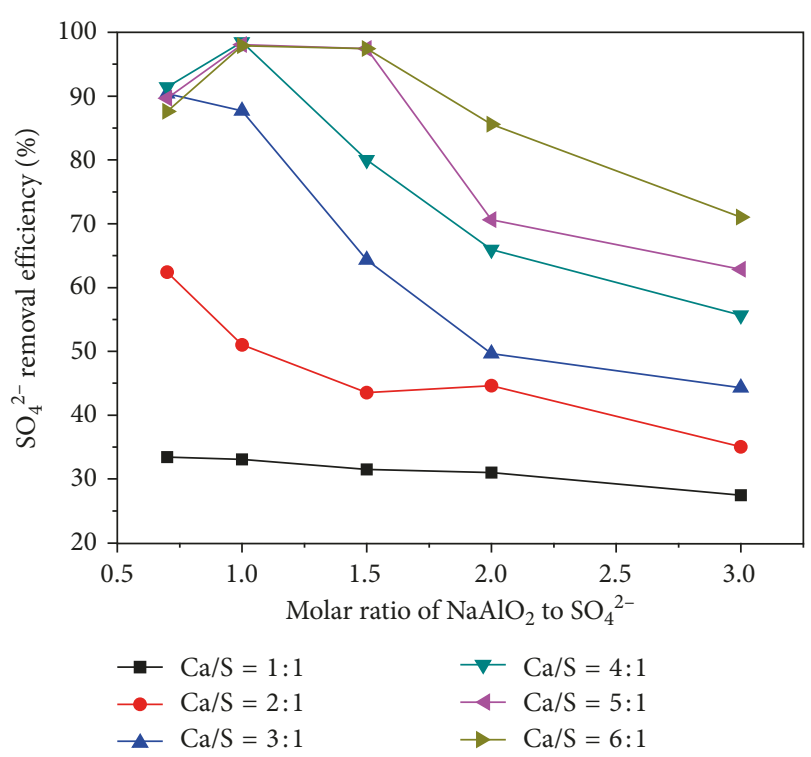

Figure 1: The effect of $\mathrm{NaAlO}_{2}$ dosage. $V_{\text {solution }}=1 \mathrm{~L}, T=25^{\circ} \mathrm{C}$, $v=200 \mathrm{r} / \mathrm{min}, t=30 \mathrm{~min}$, and $\mathrm{pH}=7.0$.

\section{Results and Discussion}

3.1. Effect of $\mathrm{NaAlO}_{2}$ Dosage and $\mathrm{Ca}(\mathrm{OH})_{2}$ Dosage. Previous researches have shown that $\mathrm{SO}_{4}{ }^{2-}$ removal was significantly affected by $\mathrm{NaAlO}_{2}$ dosage and $\mathrm{Ca}(\mathrm{OH})_{2}$ dosage $[21,22]$. So the effects of $\mathrm{NaAlO}_{2}$ dosage and $\mathrm{Ca}(\mathrm{OH})_{2}$ dosage on $\mathrm{SO}_{4}{ }^{2-}$ removal were investigated and the results are shown in Figures 1 and 2.

As depicted in Figure 1, the $\mathrm{SO}_{4}{ }^{2-}$ removal was greatly affected by the $\mathrm{NaAlO}_{2}$ dosage, but the effect of $\mathrm{NaAlO}_{2}$ dosage on the removal of sulfate was different under different molar ratios of $\mathrm{Ca}(\mathrm{OH})_{2}$ to $\mathrm{SO}_{4}{ }^{2-}(\mathrm{Ca} / \mathrm{S}$ ratio). The $\mathrm{SO}_{4}{ }^{2-}$ removal decreased with increasing $\mathrm{NaAlO}_{2}$ dosage, when the $\mathrm{Ca} / \mathrm{S}$ ratio was less than $3: 1$. However, it was found that the $\mathrm{SO}_{4}{ }^{2-}$ removal increased with the increase of the molar ratios of $\mathrm{NaAlO}_{2}$ to $\mathrm{SO}_{4}{ }^{2-}$ (Al/S ratio) at first, then decreased rapidly with the increase of $\mathrm{NaAlO}_{2}$ dosage when the $\mathrm{Ca} / \mathrm{S}$ ratio was more than $4: 1$. The theoretical $\mathrm{Al} / \mathrm{S}$ ratio found in $\mathrm{Ca}_{6} \mathrm{Al}_{2}\left(\mathrm{SO}_{4}\right)_{3}(\mathrm{OH})_{12}$ is about 0.67 ; the $\mathrm{NaAlO}_{2}$ dosage was added in excess $(\mathrm{Al} / \mathrm{S}$ ratio $\geq 0.7)$ in the series of experiments. It was found that the amount of ettringite generated was reduced with an increase of $\mathrm{NaAlO}_{2}$ dosage; meanwhile, the monosulfate $\left(\mathrm{Ca}_{4} \mathrm{Al}_{2}\left(\mathrm{SO}_{4}\right)(\mathrm{OH})_{12}\right)$ generation increased [21]. The $\mathrm{Al} / \mathrm{S}$ ratio in the monosulfate is $2: 1$ higher than the ettringite $(2: 3)$, and the $\mathrm{Ca} / \mathrm{S}$ ratio in the monosulfate is $4: 1$ higher than the ettringite $(2: 1)$. Therefore, sulfate ions are mainly removed in monosulfate form at the high $\mathrm{NaAlO}_{2}$ dosage condition, resulting in large consumption of calcium and aluminum, and reduction of sulfate ion removal. The results have shown that overdosing of $\mathrm{NaAlO}_{2}$ is not conducive to sulfate ions removal; the preferred $\mathrm{Al} / \mathrm{S}$ ratio is $1: 1$.

The effect of $\mathrm{Ca}(\mathrm{OH})_{2}$ dosage on $\mathrm{SO}_{4}{ }^{2-}$ removal is shown in Figure 2. The results show that $\mathrm{SO}_{4}{ }^{2-}$ removal increased with an increase of $\mathrm{Ca}(\mathrm{OH})_{2}$ dosage at first, then decreased slowly with the $\mathrm{Ca}(\mathrm{OH})_{2}$ dosage further increasing, when

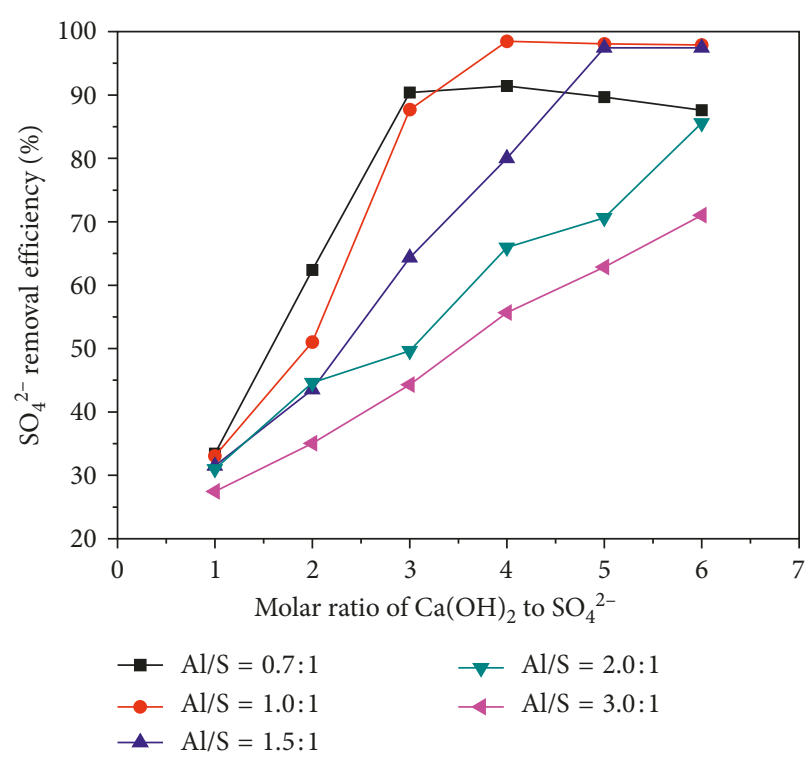

Figure 2: The effect of $\mathrm{Ca}(\mathrm{OH})_{2}$ dosage. $V_{\text {solution }}=1 \mathrm{~L}, T=25^{\circ} \mathrm{C}$, $v=200 \mathrm{r} / \mathrm{min}, t=30 \mathrm{~min}$, and $\mathrm{pH}=7.0$.

the $\mathrm{Al} / \mathrm{S}$ ratio was less than $1.5: 1$. This is because $\mathrm{Ca}^{2+}$ concentration in the solution increased with an increase of $\mathrm{Ca}(\mathrm{OH})_{2}$ dosage, which facilitated the $\mathrm{SO}_{4}{ }^{2-}$ removal. However, the $\mathrm{pH}$ of the solution increased with an increase of $\mathrm{Ca}(\mathrm{OH})_{2}$ dosage. The reaction of $\mathrm{NaAlO}_{2}$ hydrolysis could be inhibited by hydroxide ions; meanwhile, the hydroxide ions could promote the formation of monosulfate, and finally, the $\mathrm{SO}_{4}{ }^{2-}$ removal decreased with the increase of the solution $\mathrm{pH}$. When the $\mathrm{Al} / \mathrm{S}$ ratio was higher than $1.5: 1, \mathrm{SO}_{4}{ }^{2-}$ removal increased with the increase of $\mathrm{Ca}(\mathrm{OH})_{2}$ dosage. The main reason is that sulfate ions are mainly removed in the monosulfate form at the high $\mathrm{NaAlO} 2$ dosage condition. The molar ratio of $\mathrm{Ca}^{2+}$ to $\mathrm{SO}_{4}{ }^{2-}$ in the monosulfate is twice as much as that in the ettringite, and the concentration of $\mathrm{Ca}^{2+}$ in the solution increased with the $\mathrm{Ca}(\mathrm{OH})_{2}$ dosage increasing, leading to generate a large amount of ettringite. Thus, the $\mathrm{SO}_{4}{ }^{2-}$ removal increased. However, it is deduced that $\mathrm{SO}_{4}{ }^{2-}$ removal will decrease with further increase in the $\mathrm{Ca}(\mathrm{OH})_{2}$ dosage, as a large number of hydroxide ions are not conducive to the formation of ettringite. So overdosing of $\mathrm{Ca}(\mathrm{OH})_{2}$ is neither desirable nor cost-effective; the preferred $\mathrm{Ca} / \mathrm{S}$ ratio is $4: 1$.

Considering the $\mathrm{SO}_{4}{ }^{2-}$ removal and cost-effectiveness, in the next series of experiments the molar ratios of $\mathrm{Ca}(\mathrm{OH})_{2}$ to $\mathrm{NaAlO}_{2}$ to $\mathrm{SO}_{4}{ }^{2-}(\mathrm{Ca}: \mathrm{Al}: \mathrm{S})$ were constant at $4: 1: 1$. In addition, based on the literatures and experimental results $[19,21]$, the following chemical equilibrium reactions can be used to describe the $\mathrm{SO}_{4}{ }^{2-}$ removal reaction process:

$$
\begin{gathered}
\mathrm{NaAlO}_{2}+2 \mathrm{H}_{2} \mathrm{O} \longrightarrow \mathrm{NaOH}+\mathrm{Al}(\mathrm{OH})_{3} \\
\mathrm{Al}(\mathrm{OH})_{3}+\mathrm{OH}^{-} \longrightarrow \mathrm{Al}(\mathrm{OH})_{4}^{-} \\
\mathrm{Al}(\mathrm{OH})_{4}^{-}+2 \mathrm{OH}^{-} \longrightarrow\left[\mathrm{Al}(\mathrm{OH})_{6}\right]^{3-} \\
2\left[\mathrm{Al}(\mathrm{OH})_{6}\right]^{3-}+6 \mathrm{Ca}^{2+}+24 \mathrm{H}_{2} \mathrm{O} \longrightarrow \\
\left\{\mathrm{Ca}_{6}\left[\mathrm{Al}(\mathrm{OH})_{6}\right]_{2} \cdot 24 \mathrm{H}_{2} \mathrm{O}\right\}^{6+}
\end{gathered}
$$




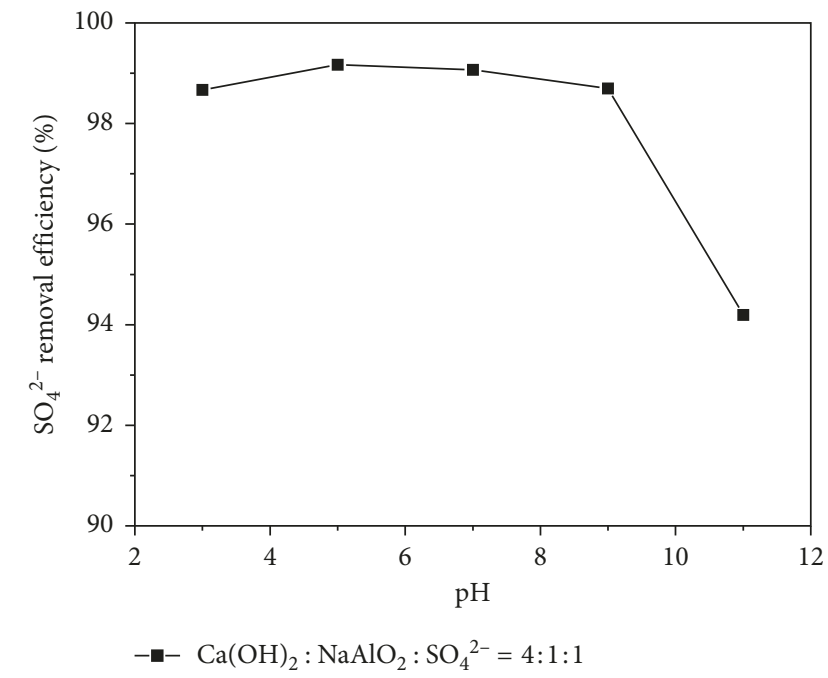

Figure 3: The effect of the solution initial pH. $v_{\text {solution }}=1 \mathrm{~L}$, $T=25^{\circ} \mathrm{C}, v=200 \mathrm{r} / \mathrm{min}$, and $t=30 \mathrm{~min}$.

$$
\begin{array}{r}
\left\{\mathrm{Ca}_{6}\left[\mathrm{Al}\left(\mathrm{OH}_{6}\right)\right]_{2} \cdot 24 \mathrm{H}_{2} \mathrm{O}\right\}^{6+}+3 \mathrm{SO}_{4}^{2-}+2 \mathrm{H}_{2} \mathrm{O} \longrightarrow \\
\left\{\mathrm{Ca}_{6}\left[\mathrm{Al}(\mathrm{OH})_{6}\right]_{2} \cdot 24 \mathrm{H}_{2} \mathrm{O}\right\}\left[\left(\mathrm{SO}_{4}\right)_{3} \cdot 2 \mathrm{H}_{2} \mathrm{O}\right] \\
=\mathrm{Ca}_{6} \mathrm{Al}_{2}\left(\mathrm{SO}_{4}\right)_{3}(\mathrm{OH})_{12} \cdot 26 \mathrm{H}_{2} \mathrm{O} \\
2 \mathrm{Al}(\mathrm{OH})_{4}^{-}+4 \mathrm{Ca}^{2+}+\mathrm{SO}_{4}^{2-}+4 \mathrm{OH}^{-} \longrightarrow \\
\mathrm{Ca}_{4} \mathrm{Al}_{2}\left(\mathrm{SO}_{4}\right)(\mathrm{OH})_{12}
\end{array}
$$

3.2. Effect of the Solution Initial $p H$. It can be seen from Figure 3 that the removal of $\mathrm{SO}_{4}{ }^{2-}$ was negligibly affected by the solution initial $\mathrm{pH}$ when the $\mathrm{pH}$ was ranging from 3.0 to 9.0 and the $\mathrm{SO}_{4}{ }^{2-}$ removal efficiencies maintained at around $99 \%$ within the $\mathrm{pH}$ range. However, $\mathrm{SO}_{4}{ }^{2-}$ removal efficiencies decreased slowly when the initial $\mathrm{pH}$ was more than 9.0; for example, the $\mathrm{SO}_{4}{ }^{2-}$ removal efficiencies decreased from $98.69 \%$ to $94.19 \%$ in the $\mathrm{pH}$ range of 9.0 11.0. There are two main reasons for this outcome. One of the reasons is that $\mathrm{Ca}(\mathrm{OH})_{2}$ solubility decreased with the increase of solution $\mathrm{pH}$, resulting in lower $\mathrm{Ca}^{2+}$ concentration in the solution and less ettringite production. Another reason is that the amount of $\mathrm{CO}_{2}$ absorbed by the solution increased with increasing alkalinity of the solution, resulting in an increase of $\mathrm{CO}_{3}{ }^{2-}$ concentration in the solution; thus $\mathrm{CO}_{3}{ }^{2-}$ can react with ettringite to form hydrated carbonated calcium aluminate $\left(3 \mathrm{CaO} \cdot \mathrm{Al}_{2} \mathrm{O}_{3} \cdot \mathrm{CaCO}_{3} \cdot 11 \mathrm{H}_{2} \mathrm{O}\right)[19,23]$, leading to decrease in $\mathrm{SO}_{4}{ }^{2-}$ removal efficiencies. Therefore, it is necessary to control the wastewater $\mathrm{pH}$ in practical engineering applications in the range of 5.0 9.0 to achieve a higher $\mathrm{SO}_{4}{ }^{2-}$ removal.

3.3. Effect of Solution Temperature. Solution temperature is one of the important factors in $\mathrm{SO}_{4}{ }^{2-}$ removal. As Figure 4 shows, $\mathrm{SO}_{4}{ }^{2-}$ removal sharply decreased from $99.29 \%$ to $37.62 \%$, when the solution temperature increased from 25 to $80^{\circ} \mathrm{C}$. The main reason is that the solubility of $\mathrm{Ca}(\mathrm{OH})_{2}$ increases with increasing temperature, and that the solution $\mathrm{pH}$

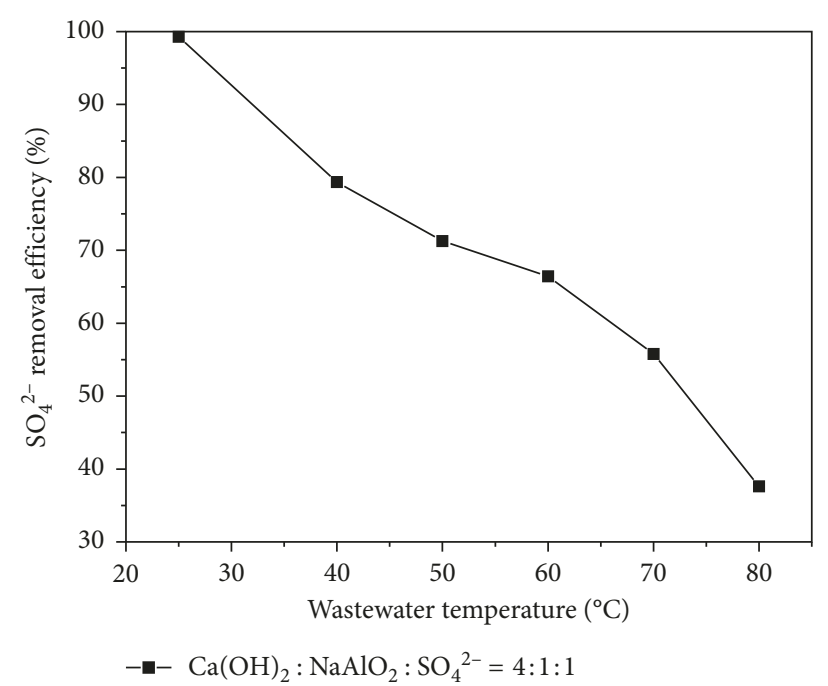

Figure 4: The effect of solution temperature. $V_{\text {solution }}=1 \mathrm{~L}$, $v=200 \mathrm{r} / \mathrm{min}, t=30 \mathrm{~min}$, and $\mathrm{pH}=7.0$.

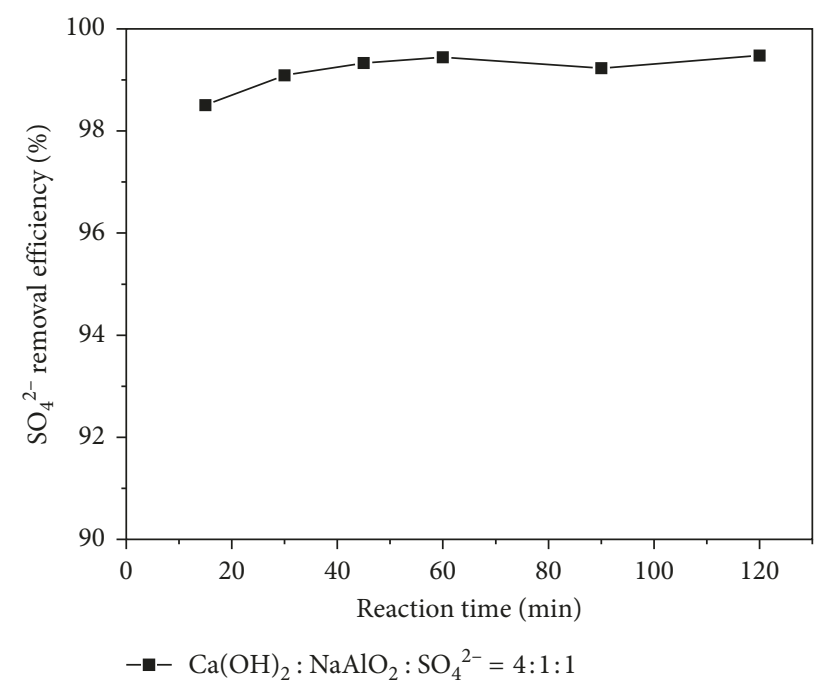

FIGURE 5: The effect of reaction time. $V_{\text {solution }}=1 \mathrm{~L}, v=200 \mathrm{r} / \mathrm{min}$, $T=25^{\circ} \mathrm{C}$, and $\mathrm{pH}=7.0$.

increases significantly with the increase of temperature. For example, when the reaction temperatures were 25 and $80^{\circ} \mathrm{C}$, the solution $\mathrm{pH}$ after the reaction were 12.8 and 13.5 , respectively. However, previous studies have shown that the optimal $\mathrm{pH}$ range for producing stability of ettringite is about $11 \sim 12.5[21,24]$. On the one hand, increasing the solution $\mathrm{pH}$ will inhibit the hydrolysis of sodium aluminate and further hinder the formation of $\mathrm{Al}(\mathrm{OH})_{4}{ }^{-}$and $\mathrm{Al}(\mathrm{OH})_{6}{ }^{3-}$; on the other hand, increasing the $\mathrm{pH}$ will promote the decomposition of ettringite [21]. In addition, the solubility of ettringite increases with increasing temperature. Therefore, in order to achieve a higher $\mathrm{SO}_{4}{ }^{2-}$ removal, it is necessary to reduce the wastewater temperature in practical engineering applications.

3.4. Effect of Reaction Time. Figure 5 displays the effect of reaction time on $\mathrm{SO}_{4}{ }^{2-}$ removal. The results show that the 


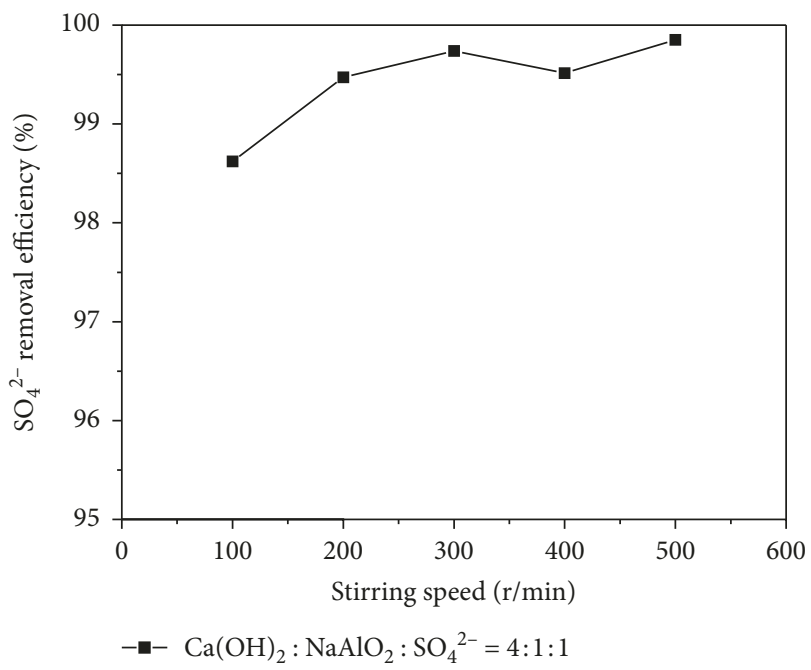

FIGURE 6: The effect of stirring speed. $V_{\text {solution }}=1 \mathrm{~L}, t=30 \mathrm{~min}$, $T=25^{\circ} \mathrm{C}$, and $\mathrm{pH}=7.0$.

reaction time has a minimal effect on $\mathrm{SO}_{4}{ }^{2-}$ removal. $\mathrm{SO}_{4}{ }^{2-}$ removal efficiencies were 98.51\%, 99.09\%, 99.33\%, 99.45\%, $99.23 \%$, and $99.48 \%$ when the reaction time were $15,30,45,60$, 90 , and $120 \mathrm{~min}$, respectively. $\mathrm{SO}_{4}{ }^{2-}$ removal slightly increased with the increase of the reaction time. However, due to the low solubility of $\mathrm{Ca}(\mathrm{OH})_{2}, \mathrm{SO}_{4}{ }^{2-}$ removal was negligibly affected by the reaction time and remained almost constant at about $99 \%$. The results show that the reaction of $\mathrm{Ca}^{2+}, \mathrm{Al}^{3+}$, and $\mathrm{SO}_{4}{ }^{2-}$ is a rapid reaction under alkaline condition, being almost complete within $30 \mathrm{~min}$. Taking into account the economic factor, area required, and $\mathrm{SO}_{4}{ }^{2-}$ removal, the reaction time was selected as $30 \mathrm{~min}$.

3.5. Effect of Stirring Speed. The influence of stirring speed on $\mathrm{SO}_{4}{ }^{2-}$ removal was investigated and the results are shown in Figure 6. The results indicate that $\mathrm{SO}_{4}{ }^{2-}$ removal was slightly affected by the stirring speed, and the $\mathrm{SO}_{4}{ }^{2-}$ removal increased slowly from $98.62 \%$ to $99.85 \%$ with the increase of stirring speed from 100 to $500 \mathrm{r} / \mathrm{min}$. In general, the increase of stirring speed helps promote the dissolution of the reagents by increasing the opportunities for contact and collision of ions and promote $\mathrm{SO}_{4}{ }^{2-}$ removal. However, in this study the increase of stirring speed cannot significantly increase the $\mathrm{SO}_{4}{ }^{2-}$ removal; the main reason is that the reaction of ettringite formation is a rapid reaction, and the appropriate stirring speed just can promote the completion of the reaction. Hence, it is not necessary to use high stirring speed to promote the reaction completion. Considering the cost and $\mathrm{SO}_{4}{ }^{2-}$ removal, the stirring speed was selected as $200 \mathrm{r} / \mathrm{min}$.

3.6. Effect of Coexisted Anions. The flue gas usually contains chloride, fluoride, nitrogen oxides, and other components; they can be absorbed by the washing liquid. Therefore, certain concentrations of chloride, fluoride, and nitrate ions will be present in the desulfurization wastewater. In this study, the effects of coexisted anions such as $\mathrm{Cl}^{-}, \mathrm{NO}_{3}{ }^{-}$, and $\mathrm{F}^{-}$on $\mathrm{SO}_{4}{ }^{2-}$ removal have been investigated, and the results are shown in Figures 7-9.

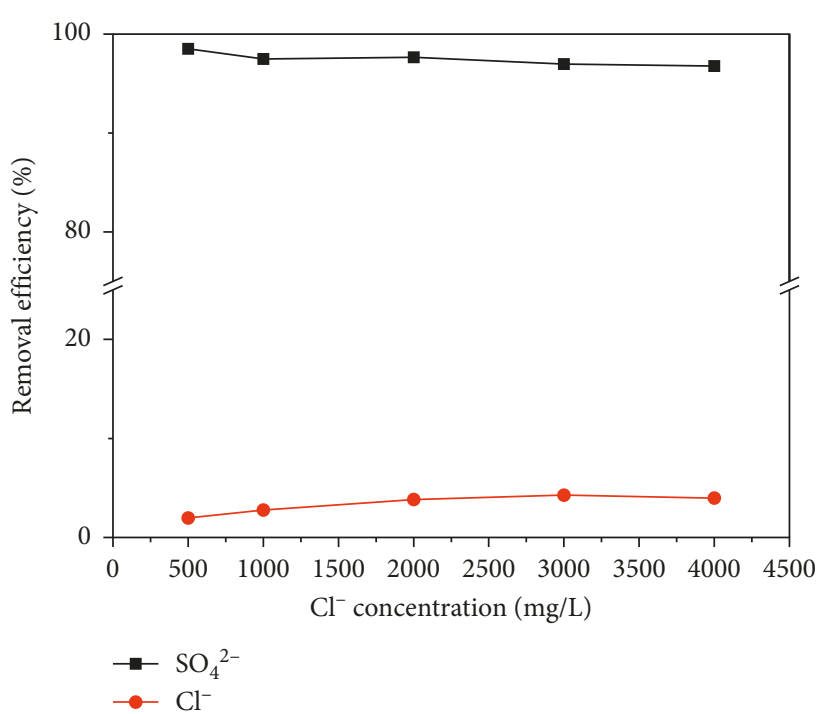

Figure 7: The effect of $\mathrm{Cl}^{-}$concentration. $V_{\text {solution }}=1 \mathrm{~L}, n(\mathrm{Ca}: \mathrm{Al}$ : S) $=4: 1: 1, v=200 \mathrm{r} / \mathrm{min}, t=30 \mathrm{~min}, T=25^{\circ} \mathrm{C}$, and $\mathrm{pH}=7.0$.

As Figure 7 illustrates, $\mathrm{SO}_{4}{ }^{2-}$ removal slowly decreased from $98.52 \%$ to $96.77 \%$ when the $\mathrm{Cl}^{-}$concentration increased from $500 \mathrm{mg} / \mathrm{L}$ to $4000 \mathrm{mg} / \mathrm{L}$. The results show that $\mathrm{SO}_{4}{ }^{2-}$ removal is negligibly affected by the low $\mathrm{Cl}^{-}$concentration (less than $2000 \mathrm{mg} / \mathrm{L}$ ), but there is a certain negative impact on the $\mathrm{SO}_{4}{ }^{2-}$ removal when the $\mathrm{Cl}^{-}$concentration is high. It was reported that $\mathrm{Cl}^{-}$can react with $\mathrm{Ca}^{2+}$ and $\mathrm{Al}^{3+}$ to form the $\mathrm{Ca}_{4} \mathrm{Al}_{2} \mathrm{Cl}_{2}(\mathrm{OH})_{12}$ [25], though the solubility products of $\mathrm{Ca}_{4} \mathrm{Al}_{2} \mathrm{Cl}_{2}(\mathrm{OH})_{12}\left(10^{-27.10}\right)$ are much less than the solubility products of $\mathrm{Ca}_{6} \mathrm{Al}_{2}\left(\mathrm{SO}_{4}\right)_{3}(\mathrm{OH})_{12}\left(10^{-111.6}\right)[20,25]$; however, the high $\mathrm{Cl}^{-}$concentration causes competitive reactions of $\mathrm{Cl}^{-}$ and $\mathrm{SO}_{4}{ }^{2-}$ for the $\mathrm{Ca}^{2+}$ and $\mathrm{Al}^{3+}$, resulting in a decrease of $\mathrm{SO}_{4}{ }^{2-}$ removal. Overall, chloride ions have a minimal effect on the removal of sulfate ions. Compared with the high $\mathrm{SO}_{4}{ }^{2-}$ removal, $\mathrm{Cl}^{-}$removal is low. When $\mathrm{Cl}^{-}$concentration varied from $500 \mathrm{mg} / \mathrm{L}$ to $4000 \mathrm{mg} / \mathrm{L}, \mathrm{Cl}^{-}$removal almost remained stable at the range of $2 \%$ to $5 \%$. Hence, in the case of coexistence of $\mathrm{SO}_{4}{ }^{2-}$ and $\mathrm{Cl}^{-}, \mathrm{SO}_{4}{ }^{2-}$ will be first effectively removed by using this method.

As demonstrated in Figure 8, the $\mathrm{SO}_{4}{ }^{2-}$ removal was minimally affected when the $\mathrm{NO}_{3}{ }^{-}$concentration was less than $500 \mathrm{mg} / \mathrm{L}$ and remained stable at about $98 \%$. However, when the $\mathrm{NO}_{3}{ }^{-}$concentration increased from $500 \mathrm{mg} / \mathrm{L}$ to $2000 \mathrm{mg} / \mathrm{L}$, the removal of $\mathrm{SO}_{4}{ }^{2-}$ decreased from $97.76 \%$ to $90.38 \%$; meanwhile, the removal of $\mathrm{NO}_{3}{ }^{-}$almost remained stable at the range of $15 \%$ to $18 \%$ when the $\mathrm{NO}_{3}{ }^{-}$concentration increased from $500 \mathrm{mg} / \mathrm{L}$ to $2000 \mathrm{mg} / \mathrm{L}$. The main reason is that high $\mathrm{NO}_{3}{ }^{-}$concentration causes severe competitive reactions of $\mathrm{NO}_{3}{ }^{-}$and $\mathrm{SO}_{4}{ }^{2-}$ for the $\mathrm{Ca}^{2+}$ and $\mathrm{Al}^{3+}$. $\mathrm{NO}_{3}{ }^{-}$can react with $\mathrm{Ca}^{2+}$ and $\mathrm{Al}^{3+}$ to form $\mathrm{Ca}_{4} \mathrm{Al}_{2}\left(\mathrm{NO}_{3}\right)_{2}(\mathrm{OH})_{12}$ [26]; hence, $\mathrm{NO}_{3}{ }^{-}$has a negative impact on $\mathrm{SO}_{4}{ }^{2-}$ removal under high $\mathrm{NO}_{3}^{-}$concentration.

It can be seen from Figure 9 that the presence of $\mathrm{F}^{-}$in the solution has a significant inhibitory effect on $\mathrm{SO}_{4}{ }^{2-}$ removal. $\mathrm{SO}_{4}{ }^{2-}$ removal decreased rapidly from $98.49 \%$ to $61.39 \%$ when the $\mathrm{F}^{-}$concentration increased from $200 \mathrm{mg} / \mathrm{L}$ to $1000 \mathrm{mg} / \mathrm{L}$; meanwhile, the removal of $\mathrm{F}^{-}$increased slowly from $92.24 \%$ to $96.34 \%$. It is speculated that $\mathrm{F}^{-}$could react with $\mathrm{Ca}^{2+}$ to form 


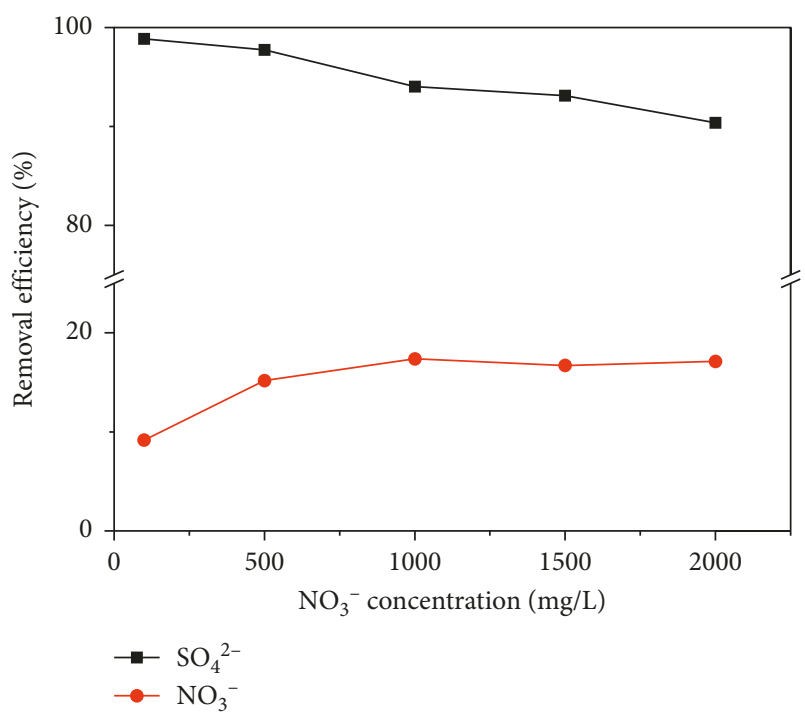

FIGURE 8: The effect of $\mathrm{NO}_{3}{ }^{-}$concentration. $V_{\text {solution }}=1 \mathrm{~L}, n(\mathrm{Ca}$ : $\mathrm{Al}: \mathrm{S})=4: 1: 1, v=200 \mathrm{r} / \mathrm{min}, t=30 \mathrm{~min}, T=25^{\circ} \mathrm{C}$, and $\mathrm{pH}=7.0$.

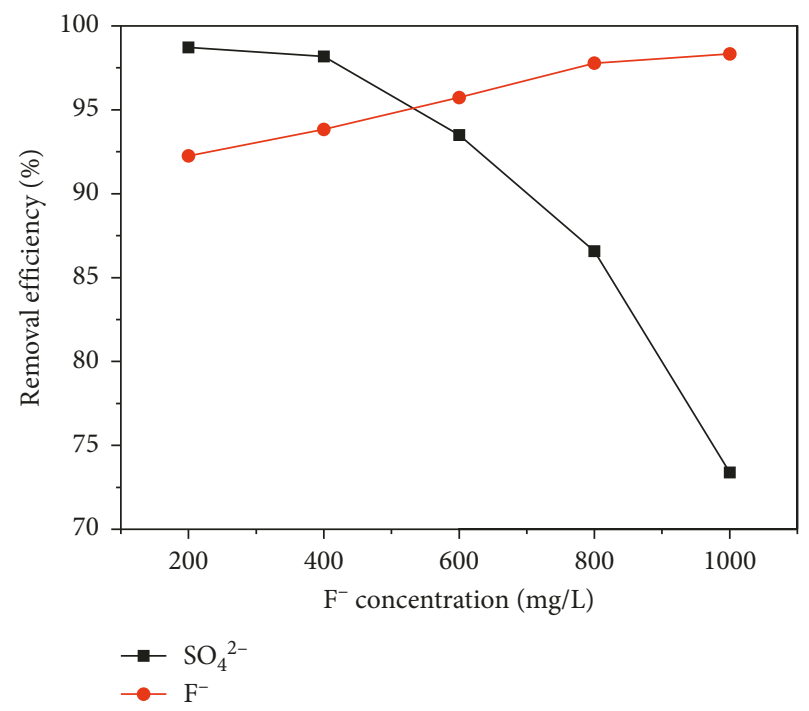

Figure 9: The effect of $\mathrm{F}^{-}$concentration. $V_{\text {solution }}=1 \mathrm{~L}, n(\mathrm{Ca}: \mathrm{Al}$ : S) $=4: 1: 1, v=200 \mathrm{r} / \mathrm{min}, t=30 \mathrm{~min}, T=25^{\circ} \mathrm{C}$, and $\mathrm{pH}=7.0$.

insoluble $\mathrm{CaF}_{2}$, so the competitive reactions of $\mathrm{Ca}^{2+}$ with $\mathrm{F}^{-}$ and $\mathrm{SO}_{4}{ }^{2-}$ existed in the solution and the amount of $\mathrm{Ca}^{2+}$ was insufficient in the solution due to the low solubility of $\mathrm{Ca}(\mathrm{OH})_{2}$; hence, $\mathrm{SO}_{4}{ }^{2-}$ removal decreased with the increase in the $\mathrm{F}^{-}$ concentration.

The research has shown that different types of anions in the solution had different effects on the removal of sulfate ions. The ability of three anions affected the $\mathrm{SO}_{4}{ }^{2-}$ removal is $\mathrm{F}^{-}>\mathrm{NO}_{3}{ }^{-}>\mathrm{Cl}^{-}$. It suggests that if the wastewater contains high concentrations of $\mathrm{F}^{-}$and $\mathrm{SO}_{4}{ }^{2-}, \mathrm{F}^{-}$must first be removed in order to achieve high $\mathrm{SO}_{4}{ }^{2-}$ removal.

3.7. Effect of Coexisted Heavy Metal Ions. A variety of heavy metal ions such as $\mathrm{Pb}^{2+}, \mathrm{Ni}^{2+}, \mathrm{Mg}^{2+}$, and $\mathrm{Mn}^{2+}$ usually exist in the desulfurization absorption solution. The flue gas is

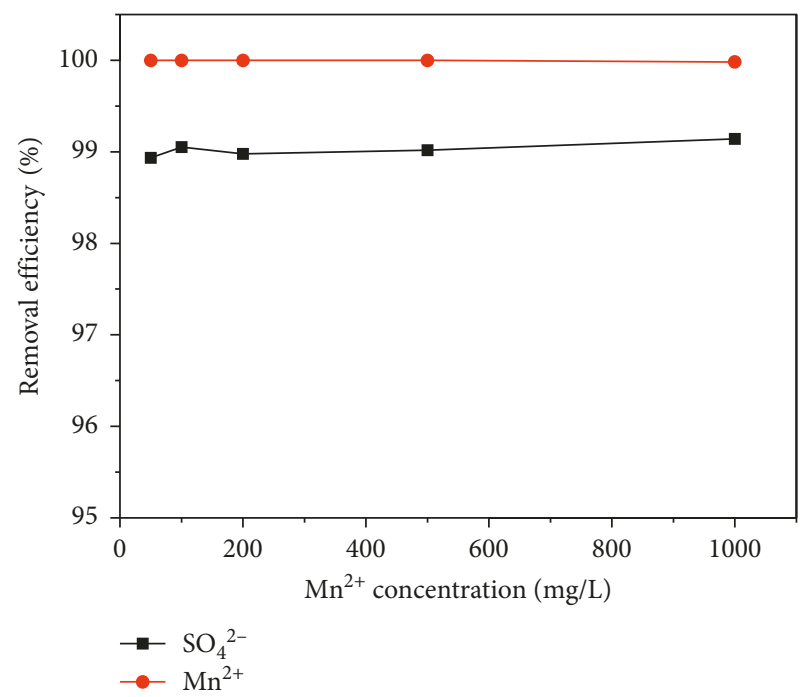

Figure 10: The effect of $\mathrm{Mn}^{2+}$ concentration. $V_{\text {solution }}=1 \mathrm{~L}, n(\mathrm{Ca}$ : $\mathrm{Al}: \mathrm{S})=4: 1: 1, v=200 \mathrm{r} / \mathrm{min}, t=30 \mathrm{~min}, T=25^{\circ} \mathrm{C}$, and $\mathrm{pH}=7.0$.

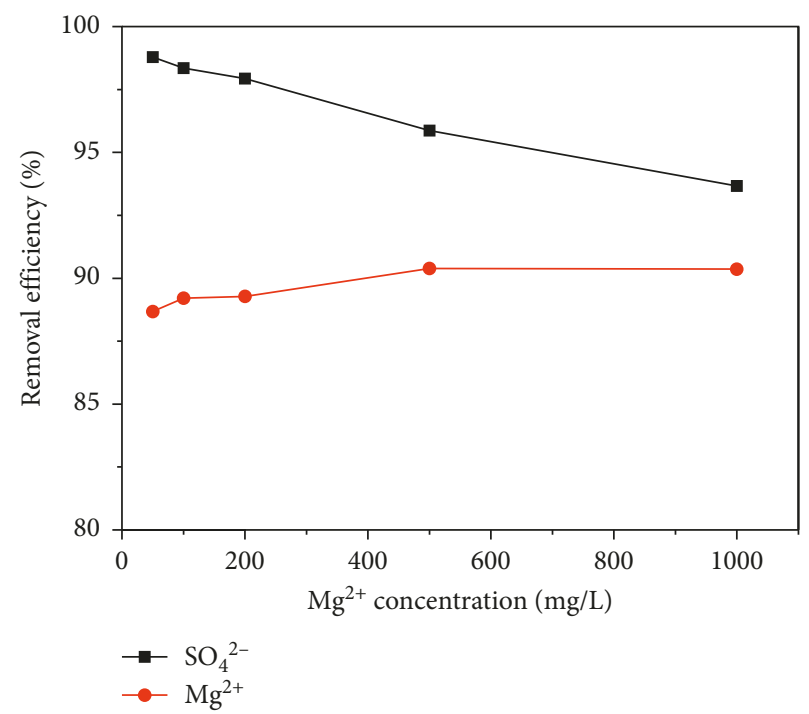

Figure 11: The effect of $\mathrm{Mg}^{2+}$ concentration. $V_{\text {solution }}=1 \mathrm{~L}, n(\mathrm{Ca}$ : $\mathrm{Al}: \mathrm{S})=4: 1: 1, v=200 \mathrm{r} / \mathrm{min}, t=30 \mathrm{~min}, T=25^{\circ} \mathrm{C}$, and $\mathrm{pH}=7.0$.

a major source of heavy metal ions; in addition to circulating water, the reagents also typically contain a certain amount of heavy metal ions. As the flue gas desulfurization absorption solution is usually alkaline in the sodium alkali $(\mathrm{NaOH})$ FGD process, some types of heavy metal ions such as $\mathrm{Pb}^{2+}$ and $\mathrm{Ni}^{2+}$ easily react with $\mathrm{OH}^{-}$to form hydroxide precipitates; therefore, the concentrations of these heavy metal ions in the solution are relatively low. It was found that $\mathrm{Mn}^{2+}$ and $\mathrm{Mg}^{2+}$ concentrations in the desulfurization wastewater were usually high. Hence, the study focused on the effect of $\mathrm{Mn}^{2+}$ and $\mathrm{Mg}^{2+}$ on $\mathrm{SO}_{4}{ }^{2-}$ removal, and the results are displayed in Figures 10 and 11.

Data shown in Figure 10 indicate that manganese ions have no effect on $\mathrm{SO}_{4}{ }^{2-}$ removal, when using the ettringite precipitation method. The removal of $\mathrm{SO}_{4}{ }^{2-}$ and $\mathrm{Mn}^{2+}$ 
almost remained stable at $99 \%$ and $100 \%$, respectively, when $\mathrm{Mn}^{2+}$ concentration increased from $50 \mathrm{mg} / \mathrm{L}$ to $1000 \mathrm{mg} / \mathrm{L}$. This is because the solution is strongly alkaline due to the addition of excess calcium hydroxide; $\mathrm{Mn}^{2+}$ can easily react with $\mathrm{OH}^{-}$to form insoluble manganese hydroxide $(\mathrm{pKsp}=13.40)$ under strong alkaline conditions. Hence, $\mathrm{Mn}^{2+}$ preferentially converts to $\mathrm{Mn}(\mathrm{OH})_{2}$ under the experimental conditions and has no effect on $\mathrm{SO}_{4}{ }^{2-}$ removal.

As shown in Figure 11, magnesium ions have a certain impact on the removal of sulfate ions. The removal of $\mathrm{SO}_{4}{ }^{2-}$ decreased from $98.78 \%$ to $93.67 \%$, when the $\mathrm{Mg}^{2+}$ concentration increased from $50 \mathrm{mg} / \mathrm{L}$ to $1000 \mathrm{mg} / \mathrm{L}$; meanwhile, the $\mathrm{Mg}^{2+}$ removal was almost maintained at between $88.68 \%$ and $90.36 \%$. Previous researches have revealed that $\mathrm{Mg}^{2+}$ can react with $\mathrm{OH}^{-}$to convert to $\mathrm{Mg}(\mathrm{OH})_{4}{ }^{2-}$ which preferentially reacts with $\mathrm{Al}(\mathrm{OH})_{4}{ }^{-}$and $\mathrm{SO}_{4}{ }^{2-}$ to form hydrotalcite-type compound $\left(\mathrm{Mg}_{6} \mathrm{Al}_{2} \mathrm{SO}_{4}(\mathrm{OH})_{16} \cdot \mathrm{nH}_{2} \mathrm{O}\right)$ rather than ettringite $\left(\mathrm{Ca}_{6} \mathrm{Al}_{2}(\mathrm{OH})_{12}\left(\mathrm{SO}_{4}\right)_{3} \cdot 26 \mathrm{H}_{2} \mathrm{O}\right)$ [19, 27]. Comparing the two chemical formulas, it can be found that the $\mathrm{Al} / \mathrm{S}$ ratio is $2: 1$ in hydrotalcite-type compound, which is three times of that in ettringite, and the molar ratio of $\mathrm{OH}^{-}$to $\mathrm{SO}_{4}{ }^{2-}$ in hydrotalcitetype compound is four times of that in ettringite. It can be derived from the results that hydrotalcite-type compound consumes more $\mathrm{Al}^{3+}$ and $\mathrm{OH}^{-}$compared with ettringite, resulting in the decrease of $\mathrm{Al}^{3+}$ and $\mathrm{OH}^{-}$concentrations in the solution, and finally, resulting in a decline of $\mathrm{SO}_{4}{ }^{2-}$ removal. Thus, in the coexistence of $\mathrm{Mg}^{2+}$ and $\mathrm{Ca}^{2+}, \mathrm{Mg}^{2+}$ can compete with $\mathrm{Ca}^{2+}$ for $\mathrm{Al}^{3+}$ to form hydrotalcite-type compound, and the higher the concentration of magnesium ions, the stronger the inhibitory effect of magnesium ion on the $\mathrm{SO}_{4}{ }^{2-}$ removal.

\subsection{Feasibility and Application Prospect of the Method.} The removal of sulfate ions and other ions in actual flue gas desulfurization wastewater by using the ettringite precipitation method was evaluated. The composition of wastewater and the results of purification various ions are shown in Tables 1 and 2. The results indicate that the ettringite precipitation method had high removal efficiencies for $\mathrm{SO}_{4}{ }^{2-}, \mathrm{F}^{-}$, and heavy metal ions, with average removal efficiencies of more than $98 \%, 90 \%$, and $99 \%$, respectively. In addition, $\mathrm{Cl}^{-}$and $\mathrm{NO}_{3}{ }^{-}$could also be removed minimally by the method.

The results show that the removal of high-concentration sulfate ions from the sodium alkali FGD wastewater is feasible by using the ettringite precipitation method. The $\mathrm{SO}_{4}{ }^{2-}$ concentration in the purified wastewater met the requirements for reuse of water which is $250 \mathrm{mg} / \mathrm{L}$ in China; meanwhile, $\mathrm{F}^{-}$ and heavy metal ions were effectively removed. As displayed in Table 1, the $\mathrm{pH}$ of the purified wastewater was 13.1; thus, the water could be reused to decrease the consumption of water and alkali in the flue gas treatment system and to reduce the operating costs. In addition, the solid sediment produced by wastewater treatment can be used as a raw material for ceramics and other building materials production. Therefore, considering the cost-effectiveness, pollutant removal efficiencies, and resource reuse, the ettringite precipitation method has the potential to be a commercial application in the field of removal of high-concentration sulfate ions from the industrial wastewater in the future.

\section{Conclusions}

In this paper, the ettringite precipitation method was used to remove the sulfate ions, and the influences of experimental parameters on $\mathrm{SO}_{4}{ }^{2-}$ removal were investigated. Based on the results of the experiments, the following conclusions can be obtained:

(1) The ettringite precipitation method can effectively synergistically remove $\mathrm{SO}_{4}{ }^{2-}, \mathrm{F}^{-}$, and heavy metal ions with removal efficiencies of more than $98 \%$, $90 \%$, and $99 \%$, respectively. In addition, $\mathrm{Cl}^{-}$and $\mathrm{NO}_{3}{ }^{-}$also can be removed minimally by the method.

(2) $\mathrm{NaAlO}_{2}$ dosage, $\mathrm{Ca}(\mathrm{OH})_{2}$ dosage, solution initial $\mathrm{pH}$, solution temperature, reaction time, stirring speed, anions $\left(\mathrm{Cl}^{-}, \mathrm{NO}_{3}^{-}\right.$and $\left.\mathrm{F}^{-}\right)$, and heavy metal ions all have effects on the $\mathrm{Cl}^{-}$removal. Finally, the optimal experimental conditions (Al/S ratio, $1: 1$; $\mathrm{Ca} / \mathrm{S}$ ratio, $4: 1$; solution temperature, $25^{\circ} \mathrm{C}$; reaction time, $30 \mathrm{~min}$; and stirring speed, $200 \mathrm{r} / \mathrm{min}$ ) were determined.

(3) The ettringite precipitation method is feasible for treating high-concentration sulfate wastewater and has the potential to be a commercial application in the high-concentration sulfate wastewater treatment field in the future.

\section{Conflicts of Interest}

The authors declare that they have no conflicts of interest.

\section{Acknowledgments}

This work was supported by the National Key R\&D Program of China (2017YFC0210704 and 2017YFC0210803), National Natural Science Foundation of China (NSFC-51778264), Project of Science and Technology Program of Guangdong Province (2015A020220008, 2015B020215008, 2016B020241002, and 2017B020237002), Youth Top-Notch Talent Special Support Program of Guangdong Province (2016TQ03Z576), and Pearl River S\&T Nova Program of Guangzhou (201610010150).

\section{References}

[1] P. Fang, Z. J. Tang, X. B. Chen et al., "Split, partial oxidation and mixed absorption: a novel process for synergistic removal of multiple pollutants from simulated flue gas," Industrial \& Engineering Chemistry Research, vol. 56, no. 17, pp. 5116-5126, 2017.

[2] W. Cao, Z. Dang, X. Q. Zhou et al., "Removal of sulphate from aqueous solution using modified rice straw: preparation, characterization and adsorption performance," Carbohydrate Polymers, vol. 85, no. 3, pp. 571-577, 2011.

[3] I. Pikaar, K. R. Sharma, S. Hu, W. Gernjak, J. Keller, and Z. Yuan, "Reducing sewer corrosion through integrated urban water management," Science, vol. 345, no. 6198, pp. 812-814, 2014.

[4] H. Sun, B. Shi, F. Yang, and D. Wang, "Effects of sulfate on heavy metal release from iron corrosion scales in drinking water distribution system," Water Research, vol. 114, pp. 69-77, 2017.

[5] D. S. Baldwin and A. Mitchell, "Impact of sulfate pollution on anaerobic biogeochemical cycles in a wetland sediment," Water Research, vol. 46, no. 4, pp. 965-974, 2012. 
[6] A. M. Silva, R. M. F. Lima, and V. A. Leao, "Mine water treatment with limestone for sulfate removal," Journal of Hazardous Materials, vol. 221-222, pp. 45-55, 2012.

[7] T. Najib, M. Solgi, A. Farazmand, S. M. Heydarian, and B. Nasernejad, "Optimization of sulfate removal by sulfate reducing bacteria using response surface methodology and heavy metal removal in a sulfidogenic UASB reactor," Journal of Environmental Chemical Engineering, vol. 5, no. 4, pp. 3256-3265, 2017.

[8] M. Gopi Kiran, K. Pakshirajan, and G. Das, "Heavy metal removal from multicomponent system by sulfate reducing bacteria: mechanism and cell surface characterization," Journal of Hazardous Materials, vol. 324, pp. 62-70, 2017.

[9] H. Lu, W. Zou, P. Chai, J. Wang, and L. Bazinet, "Feasibility of antibiotic and sulfate ions separation from wastewater using electrodialysis with ultra-filtration membrane," Journal of Cleaner Production, vol. 112, pp. 3097-3105, 2016.

[10] S. Q. Hong, F. S. Cannon, P. Hou, T. Byrne, and C. NietoDelgado, "Adsorptive removal of sulfate from acid mine drainage by polypyrrole modified activated carbons: effects of polypyrrole deposition protocols and activated carbon source," Chemosphere, vol. 184, pp. 429-437, 2017.

[11] O. Calinescu, N. M. Marin, D. Ionita et al., "Selective removal of sulfate ion from different drinking waters," Environmental Nanotechnology, Monitoring and Management, vol. 6, pp. 164-168, 2016.

[12] N. Arahman, S. Mulyati, M. RahmahLubis, R. Takagi, and H. Matsuyama, "Removal profile of sulfate ion from mix ion solution with different type and configuration of anion exchange membrane in electrodialysis," Journal of Water Process Engineering, vol. 20, pp. 173-179, 2017.

[13] M. A. Mamelkina, S. Cotillas, E. Lacasa et al., "Removal of sulfate from mining waters by electrocoagulation," Separation and Purification Technology, vol. 182, pp. 87-93, 2017.

[14] S. Tait, W. P. Clarke, J. Keller, and D. J. Batstone, "Removal of sulfate from high-strength wastewater by crystallization," Water Research, vol. 43, no. 3, pp. 762-772, 2009.

[15] M. D. G. Luna, D. P. M. Rance, L. M. Bellotindos, and M. C. Lu, "Removal of sulfate by fluidized bed crystallization process," Journal of Environmental Chemical Engineering, vol. 5, no. 3, pp. 2431-2439, 2017.

[16] C. T. Benatti, C. R. G. Tavares, and E. Lenzi, "Sulfate removal from waste chemicals by precipitation," Journal of Environmental Management, vol. 90, no. 1, pp. 504-511, 2009.

[17] H. Runtti, T. Luukkonen, M. Niskanen et al., "Sulphate removal over barium-modified blast-furnace-slag geopolymer," Journal of Hazardous Materials, vol. 317, pp. 373-384, 2016.

[18] D. N. Kartic, B.C. H. A. Narayana, and M. Arivazhagan, "Removal of high concentration of sulfate from pigment industry effluent by chemical precipitation using barium chloride: RSM and ANN modeling approach," Journal of Environmental Management, vol. 206, pp. 69-76, 2018.

[19] W. X. Dou, Z. Zhou, L. M. Jiang et al., "Sulfate removal from wastewater using ettringite precipitation: magnesium ion inhibition and process optimization," Journal of Environmental Management, vol. 196, pp. 518-526, 2017.

[20] E. T. Tolonen, T. Hu, J. Ramo, and U. Lassi, "The removal of sulphate from mine water by precipitation as ettringite and the utilisation of the precipitate as a sorbent for arsenate removal," Journal of Environmental Management, vol. 181, pp. 856-862, 2016.

[21] D. Almasri, K. A. Mahmoud, and A. Abdel-Wahab, "Twostage sulfate removal from reject brine in inland desalination with zero-liquid discharge," Desalination, vol. 362, pp. 52-58, 2015.
[22] I. Kabdasl, A. Bilgin, and O. Tünay, "Sulphate control by ettringite precipitation in textile industry wastewaters," Environmental Technology, vol. 37, no. 4, pp. 446-451, 2016.

[23] H. Z. Ma and M. Deng, "Effect of alkali on ettringite crystallization and solubility," Journal of Nanjing University of Technology, vol. 29, pp. 37-40, 2007, in Chinese.

[24] M. Chrysochoou and D. Dermatas, "Evaluation of ettringite and hydrocalumite formation for heavy metal immobilization: literature review and experimental study," Journal of Hazardous Materials, vol. 136, no. 1, pp. 20-33, 2006.

[25] A. Abdel-Wahab, B. Batchelor, and J. Schwantes, "An equilibrium model for chloride removal from recycled cooling water using the ultra-high lime with aluminum process," Water Environment Research, vol. 77, no. 7, pp. 3059-3065, 2005.

[26] J. P. Rapin, G. Renaudin, E. Elkaim, and M. Francois, "Structural transition of Friedel's salt $3 \mathrm{CaO} \cdot \mathrm{Al}_{2} \mathrm{O}_{3} \cdot \mathrm{CaCl}_{2} \cdot 10 \mathrm{H}_{2} \mathrm{O}$ studied by synchrotron powder diffraction," Cement and Concrete Research, vol. 32, no. 4, pp. 513-519, 2002.

[27] R. Shi, P. Yang, Y. Yin, X. Dong, and J. Li, "Fabrication of porous microspheres and network arrays of $\mathrm{Zn}$-Al hydrotalcite-like compounds on $\mathrm{Al}$ substrate via facile hydrothermal method," Ceramics International, vol. 40, no. 5, pp. 6855-6863, 2014. 

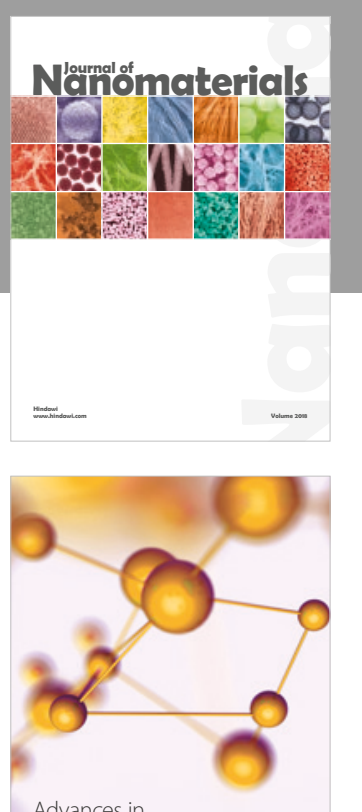

Physical Chemistry
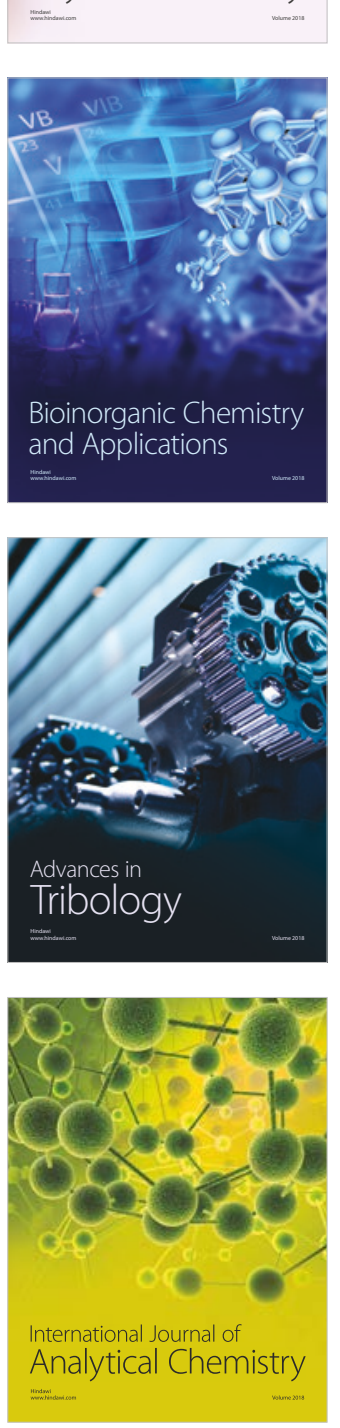

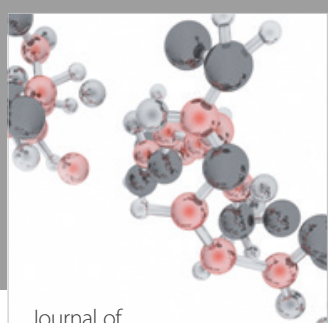

Analytical Methods

in Chemistry

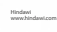

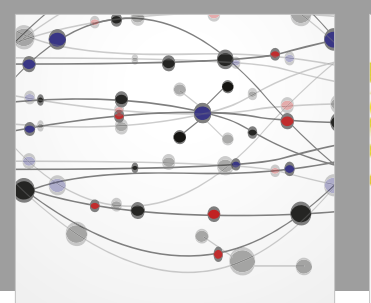

The Scientific World Journal

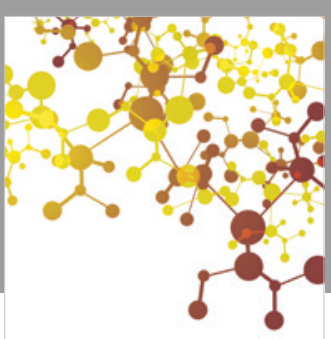

Journal of

Applied Chemistry
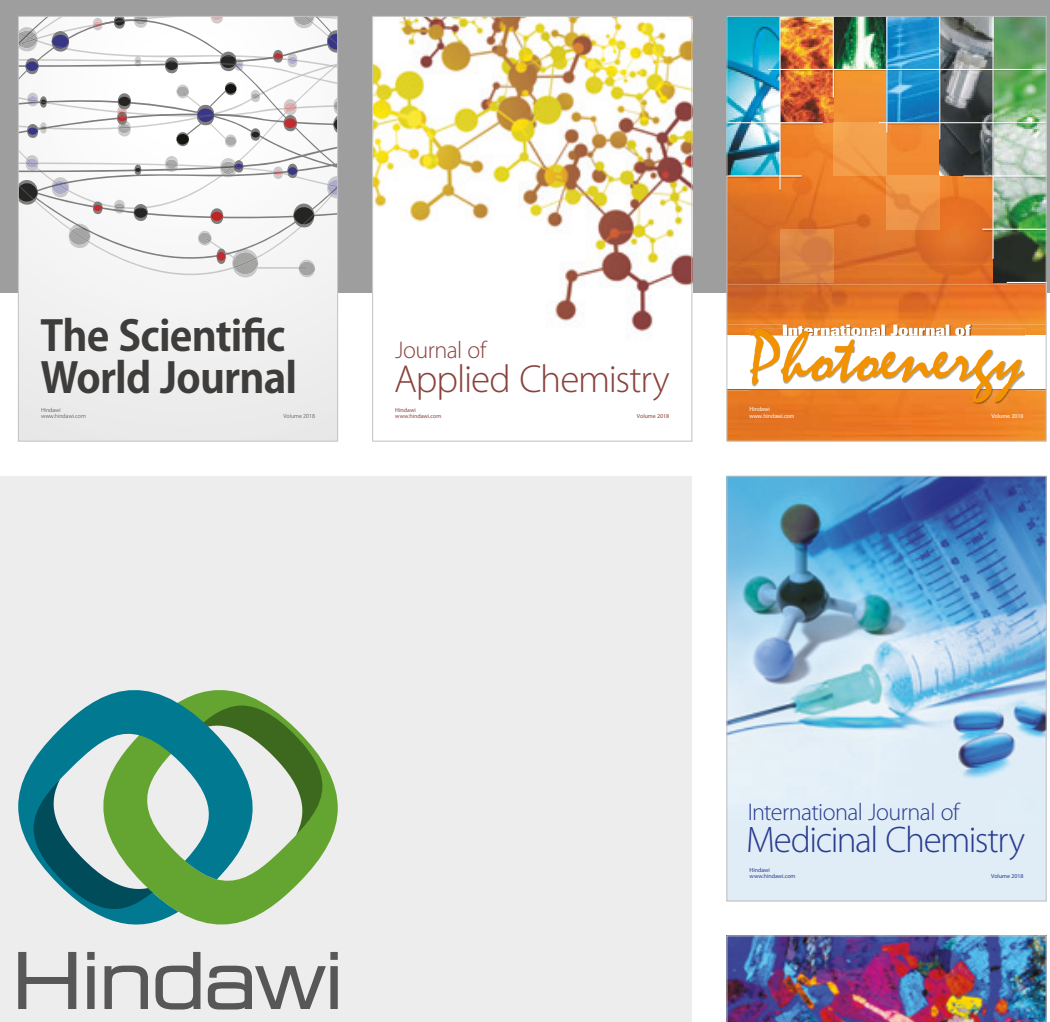

Submit your manuscripts at

www.hindawi.com
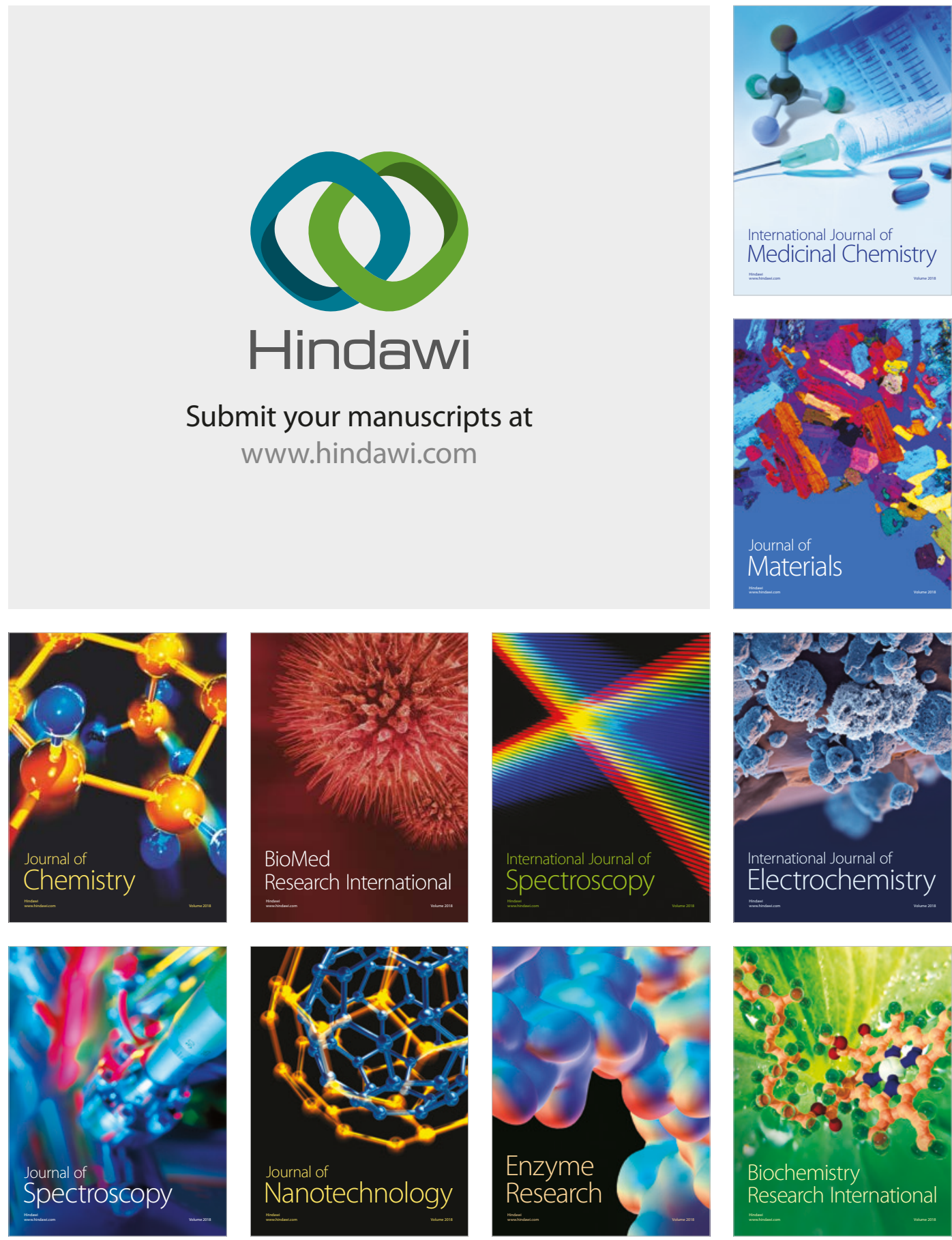
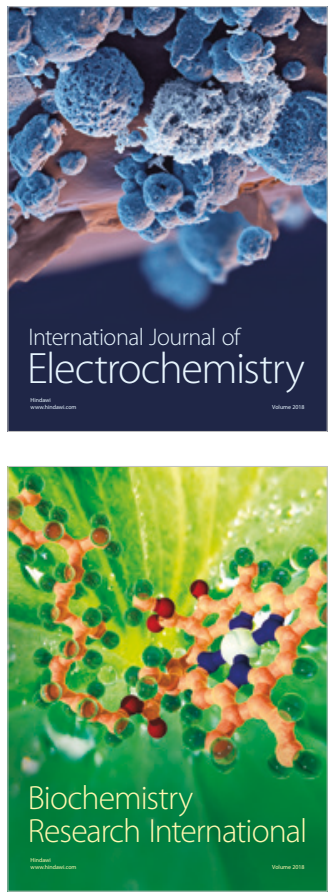